\title{
The Thermal Decomposition of Ammonium Perchlorate-Aluminum Propellants in Presence of Metallic Zinc Particles
}

\author{
Mónica Rodríguez-Pesina', Jorge García-Domínguez², Felipe García-Hernández², \\ Luisa Maria Flores-Vélez ${ }^{3}$, Octavio Domínguez ${ }^{{ }^{*}}$ \\ ${ }^{1}$ Institute of Metallurgy, UASLP, San Luis Potosi, México \\ ${ }^{2}$ INIDETAM, Polígono Naval, Antón Lizardo, Veracruz, México \\ ${ }^{3}$ Faculty of Chemistry, UASLP, San Luis Potosi, México \\ Email: ^nanochimica@yahoo.com
}

How to cite this paper: Rodríguez-Pesina, M., García-Domínguez, J., García-Hernández, F., Flores-Vélez, L.M. and Domínguez, O. (2017) The Thermal Decomposition of Ammonium Perchlorate-Aluminum Propellants in Presence of Metallic Zinc Particles. Materials Sciences and Applications, 8, 436-447. https://doi.org/10.4236/msa.2017.86030

Received: February 15, 2017

Accepted: June 9, 2017

Published: June 12, 2017

Copyright $\odot 2017$ by authors and Scientific Research Publishing Inc. This work is licensed under the Creative Commons Attribution International License (CC BY 4.0).

http://creativecommons.org/licenses/by/4.0/

\begin{abstract}
The thermal decomposition of ammonium perchlorate (AP) with $\mathrm{Al}$ and $\mathrm{Zn}$ metallic particles was studied at different heating rates in dry air atmosphere and the combustion behavior of $\mathrm{AP} / \mathrm{Al} / \mathrm{Zn}$ propellant was evaluated. The exothermic reaction kinetics was studied by differential thermal analysis (DTA) in non-isothermal conditions and compare with the thermal decomposition of pure $\mathrm{AP}$ and $\mathrm{AP} /$ aluminum particles analyzed in the same experimental conditions. The Arrhenius parameters were estimated according to the Ozawa and Kissinger methods. The calculated activation energies for the low and high temperature exothermic reactions were 91 and $229 \mathrm{~kJ} / \mathrm{mol}$ for pure AP, 90 and $112 \mathrm{~kJ} / \mathrm{mol}$ for $80 \mathrm{wt} \% \mathrm{AP} / 20 \mathrm{wt} \% \mathrm{Al}$ particles. When zinc was incorporated, activation energy of $56 \mathrm{~kJ} / \mathrm{mol}$ was determined for the only exothermic peak observed for $90 \mathrm{wt} \% \mathrm{AP} / 10 \mathrm{wt} \% \mathrm{Zn}$ and $44 \mathrm{~kJ} / \mathrm{mol}$ for $78.4 \mathrm{wt} \%$ $\mathrm{AP} / 19.6 \mathrm{wt} \% \mathrm{Al} / 2 \mathrm{wt} \% \mathrm{Zn}$ propellant composition.
\end{abstract}

\section{Keywords}

Thermal Analysis, Ozawa Method, Kissinger Method, Thermal

Decomposition, Ammonium Perchlorate, Propellants

\section{Introduction}

For composite propellants, there are a number of common ingredients such as oxidizer, fuel and additives playing a profound effect on the propellant combustion. Ammonium perchlorate $\mathrm{NH}_{4} \mathrm{ClO}_{4}(\mathrm{AP})$ is one of the best known oxidizers capable to produce large amounts of hot gases to create thrust by expansion in 
the nozzle. AP combustion is remarkably catalyzed with transition metal oxide additives in relatively small amounts [1] [2] [3]. Fuel, the other relevant component in composite propellant composition, consists basically of micrometric metallic particles usually constituting 5 to $20 \%$ of the propellant by weight [4], being aluminum $(\mathrm{Al})$ the most common fuel nowadays [5]. Other metallic systems, as magnesium $(\mathrm{Mg})$ and magnesium/aluminum alloys, have been used in some clean formulas with reduced exhaust emissions [6]. Concerning the employment of metallic zinc ( $\mathrm{Zn})$ powder as a fuel, long time ago it was used together with sulphur (S) but there is scarce information and just recently some data has been published using zinc nanometric particles [7] and other metallic nanoparticles [8] together with AP.

One of the problems of using transition metal oxides like copper oxides and copper chromites to catalyze AP combustion, is the potential chemical reduction of such oxides by the presence of metallic aluminum leading to the presence of low melting point products capable to block the nozzle throat. In this preliminary work, mixtures of micrometric zinc powders together with AP oxidizer were prepared and the effect of chemical composition was investigated by thermal analysis experiments. The current work incorporates zinc particles on ammonium perchlorate to observe the thermal decomposition, and compares its behavior relative to the usual $\mathrm{AP}-\mathrm{Al}$ system and presents the thermal combustion of $\mathrm{AP} / \mathrm{Al} / \mathrm{Zn}$ propellant.

\section{Experimental Procedure}

AP was obtained by neutralization of perchloric acid $\mathrm{HClO}_{4}$ (Sigma-Aldrich ACS Reagent) with aqueous ammonia $\mathrm{NH}_{4} \mathrm{OH}$ (Fermont ACS Reagent), then dissolving the product followed of a crystallization process at a $\mathrm{pH}$ of 7.5 [9]. Domestic zinc (Galvanoquímica Mexicana) and aluminum (Metapol Inc.) powders were used as received. Differential thermal analysis DTA (Perkin Elmer DTA7) and thermogravimetric analysis (Perkin Elmer TGA7) were used to evaluate the decomposition of $\mathrm{AP} / \mathrm{Al}, \mathrm{AP} / \mathrm{Zn}$ and $\mathrm{AP} / \mathrm{Al} / \mathrm{Zn}$ in dry air at $20 \mathrm{ml} / \mathrm{min}$. All samples were placed in alumina $\left(\mathrm{Al}_{2} \mathrm{O}_{3}\right)$ open pans. Different heating rates ranging from $2.5^{\circ} \mathrm{C} / \mathrm{min}$ to $20^{\circ} \mathrm{C} / \mathrm{min}$ were used to perform kinetic analysis. Particles size of both, AP and aluminum fuel, play a significant role in the activation energy of the thermal decomposition [10]. Figure 1 shows the corresponding scanning electron microscopy (SEM) images of $\mathrm{NH}_{4} \mathrm{ClO}_{4} \mathrm{Al}$ and $\mathrm{Zn}$ powders. In the present work, $\mathrm{AP}, \mathrm{Al}$ and $\mathrm{Zn}$ particles presented a mean particle size of 200 $\mu \mathrm{m}, 50 \mu \mathrm{m}$ and $4 \mu \mathrm{m}$ respectively.

\section{Results and Discussion}

\subsection{Thermal Decomposition of AP}

Ammonium perchlorate (AP) is the most widely used oxidizer in solid composite propellants mainly because of the high oxygen content, large specific volume of product gases and extensive handling and storage experience [11]. The corresponding DTA thermograms are shown on Figure 2. Much work has been 


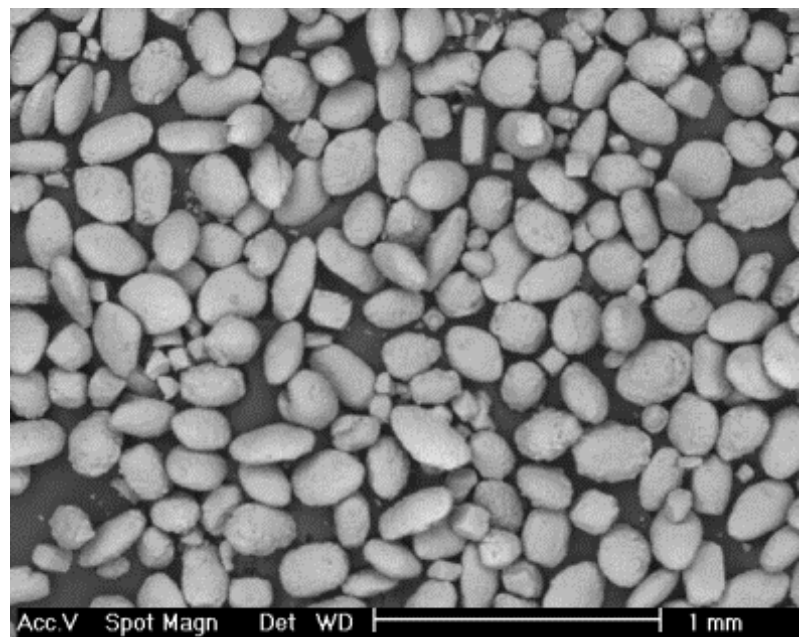

(a)

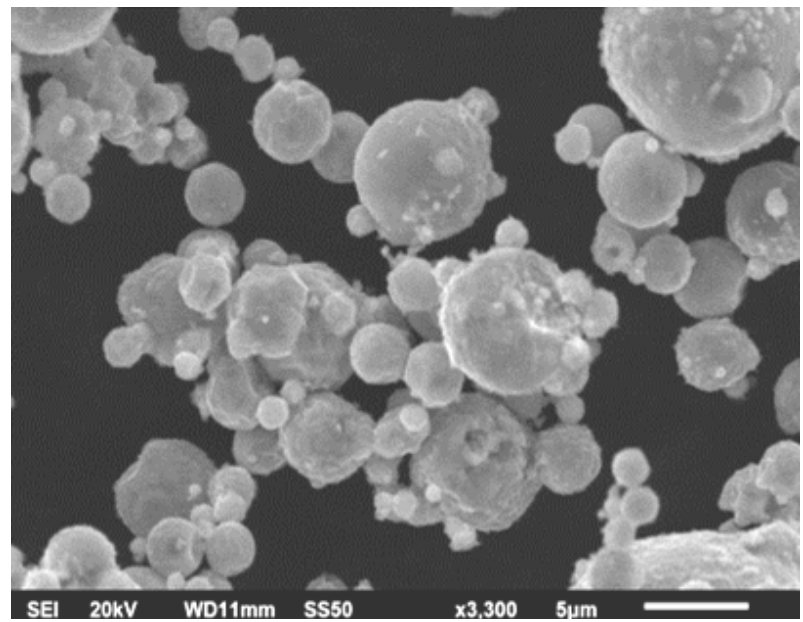

(b)

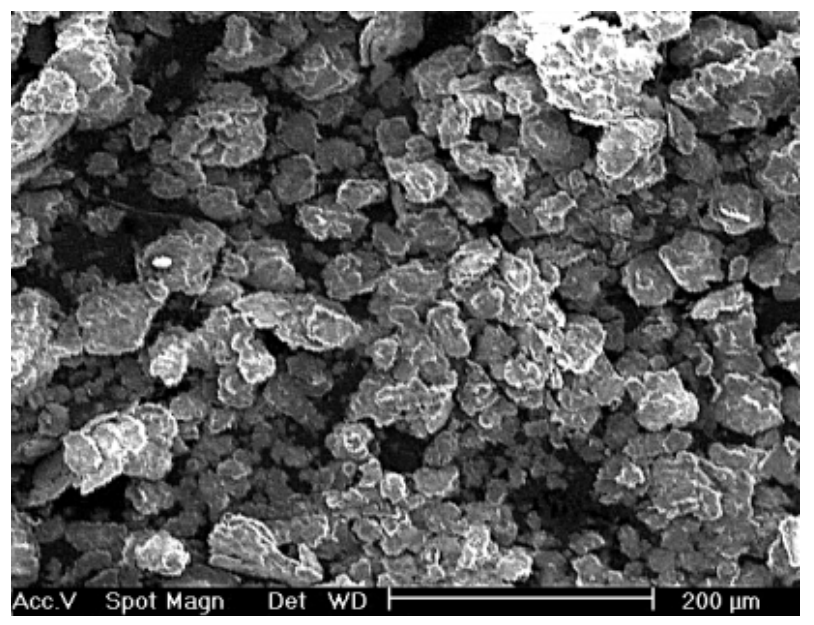

Figure 1. SEM images of: (a) $\mathrm{NH}_{4} \mathrm{ClO}_{4}$ (AP); (b) Zinc powder; (c) Aluminum powder.

done on the thermal decomposition of pure AP, existing vast reference on review articles [11] [12]. Consequently at $248^{\circ} \mathrm{C}$, all DTA curves on Figure 2 presented an endothermic peak corresponding to the structural transformation of 


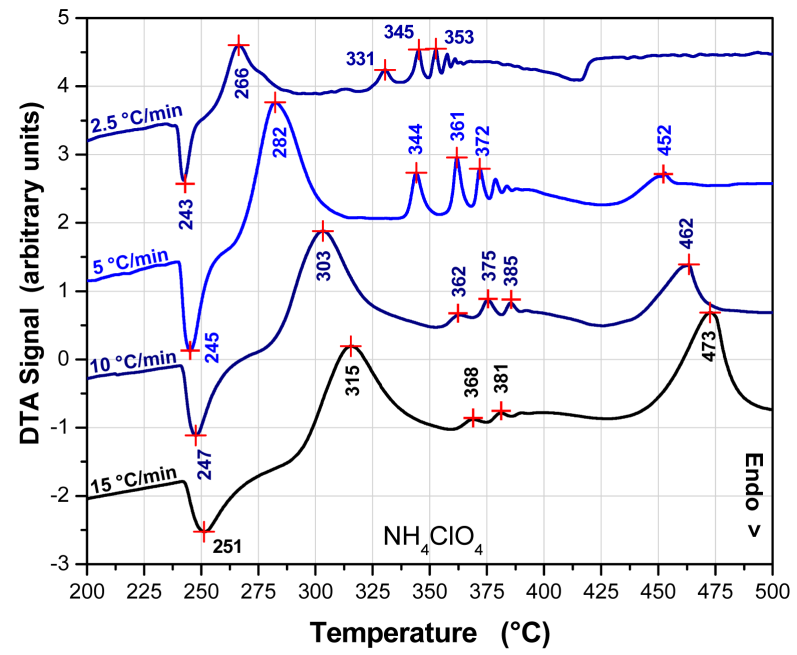

(a)

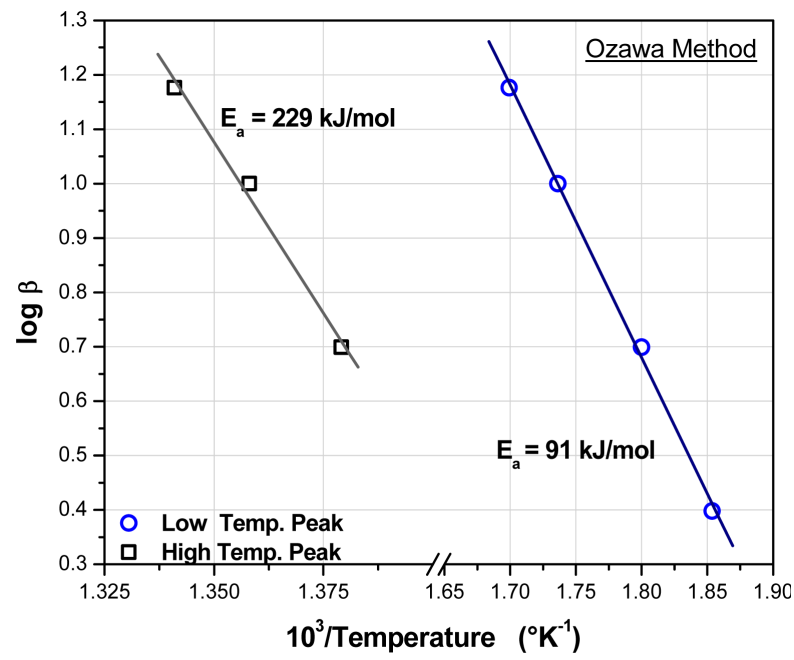

(b)

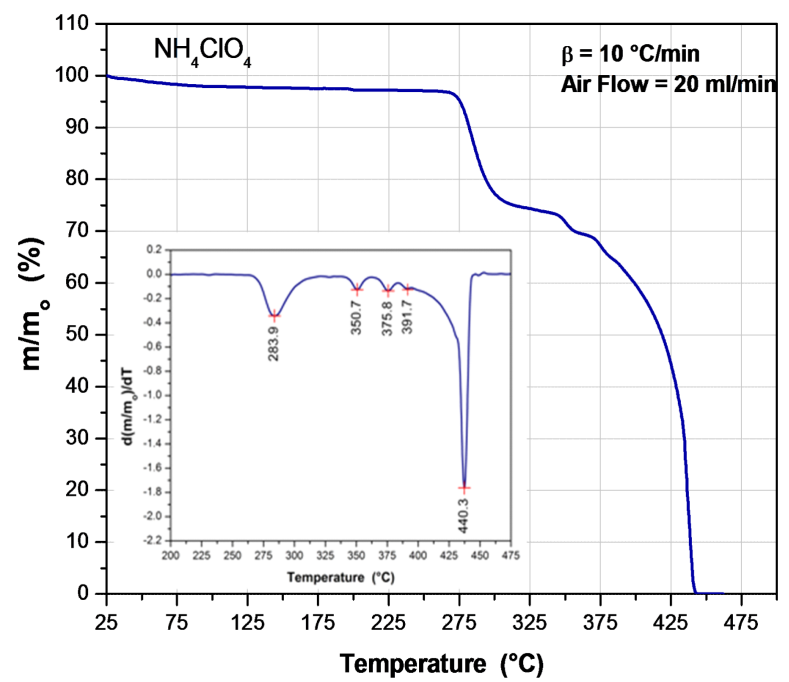

(c)

Figure 2. Thermal analysis results obtained from as-prepared AP powder (a) DTA curves at different heating rates; (b) Ozawa plots; and (c) TGA and derivative TGA curves. 
AP from the orthorhombic to cubic form. The literature on DTA/TGA data suggests that thermal decomposition of AP usually appears as a sequence of two main peaks (one at low and the other at high temperature), the first of which is exothermic. The second peak may appear as an exothermic or endothermic event, depending on the experimental conditions [13]. Different points of view exist about the mechanism of thermal decomposition of AP, nonetheless, in spite of advances in investigating the mechanism of thermal decomposition of ammonium perchlorate [11] [12] [13] [14], some aspects and sequence of reaction still remain unclear. On Figure 2 the curves obtained from DTA indicate that there are some small exothermic peaks between the two main events, all associated to some mass volatilization during the decomposition process as shown on TGA diagram presented on Figure 2(c). These small peaks could not be the noise signal of the instrument because this behavior has already been reported before [15] [16].

The thermal decomposition of any energetic material is quite important because the rate of thermal decomposition affects the quality of the material to provide thrust as well as its shelf life. The activation energy of energetic materials has been calculated before by Ozawa and Kissinger methods in double base propellants [17] and AP solid propellants [18]. The reported activation energy for low temperature AP decomposition is ranging from 80 to $115 \mathrm{~kJ} / \mathrm{mol}$, and those for high temperature decomposition between 150 and $260 \mathrm{~kJ} / \mathrm{mol}$. [11] [12] [13] [14]. In our case, the activation energy $E_{a}$ for AP was calculated by Ozawa method. In this procedure, the activation energy can be determined from plots of the logarithm of the heating rate versus the inverse of the peak temperature $T_{m}$ at constant heating rate experiments, without a precise knowledge of the reaction mechanism using the following equation [19]:

$$
\log \beta_{m}+0.4567 E_{a} / R T_{m}=\text { constant }
$$

where $\beta_{m}$ is the heating rate and $R$ the gas universal constant. Appling the method on DTA data from Figure 2(a), the activation energy of the AP decomposition was calculated only for the two main peaks, showing the corresponding results on Figure 2(b). The values obtained with the present experimental conditions are in quite good agreement with those reported previously [11] [13], finding for the low temperature peak a mean activation energy of $91 \mathrm{~kJ} / \mathrm{mol}$ and for the high temperature peak a mean activation energy of $229 \mathrm{~kJ} / \mathrm{mol}$. On the other hand, if Kissinger method is applied to all the thermal analysis results, the activation energy obtained from this procedure leads to the same values as those obtained with Ozawa equation, as shown in Table 1. Kissinger model assumes explicitly a first order reaction, making possible to calculate the pre-exponential factor A from the expression [20]:

$$
\frac{E \beta_{m}}{R T_{m}^{2}}=A \mathrm{e}^{-E_{a} / R T_{m}}
$$

\subsection{Thermal Decomposition of AP-Al System}

DTA experiments were done with aluminum particles in order to compare the 
effect of $\mathrm{Zn}$ on AP decomposition relative to the well known AP/Al system [21] [22]. Figure 3(a) shows the thermograms obtained from three different chemical compositions for $\mathrm{AP} / \mathrm{Al}$ propellants. Concerning the aluminum particles, all curves present the two main events already observed in pure AP together with the small peaks, but in this case there are another two additional peaks.

The exothermic peaks at $600^{\circ} \mathrm{C}$ on Figure 3 corresponded to the aluminum oxidation and the endothermic peaks at $661^{\circ} \mathrm{C}$ were associated to the melting point of non-reacted aluminum. Subsequently, the presence of Al particles lead to shifting the high temperature peak of AP decomposition to lower values, remaining the low temperature peak unchanged. Once more, an attempt was made to compare the kinetic parameters of non-isothermal decomposition of AP in presence of aluminum particles.

Concerning the thermal decomposition of $80 \mathrm{wt} \% \mathrm{AP}-20 \mathrm{wt} \% \mathrm{Al}$ propellant, Figure 3(b) shows that in the $\mathrm{AP} / \mathrm{Al}$ system both the low and high temperature peaks still are far away from each other even at high heating rates. Figure 3(c) presents the TGA diagram of the $80 \mathrm{wt} \% \mathrm{AP}-20 \mathrm{wt} \% \mathrm{Al}$ composition, corroborating the two main steps of the decomposition process where gases are evolved. Figure $3(d)$ presents the activation energies $E_{a}$ calculated by Ozawa method on propellant composition $80 \mathrm{AP} 20 \mathrm{Al}$. The values obtained for AP/Aluminum

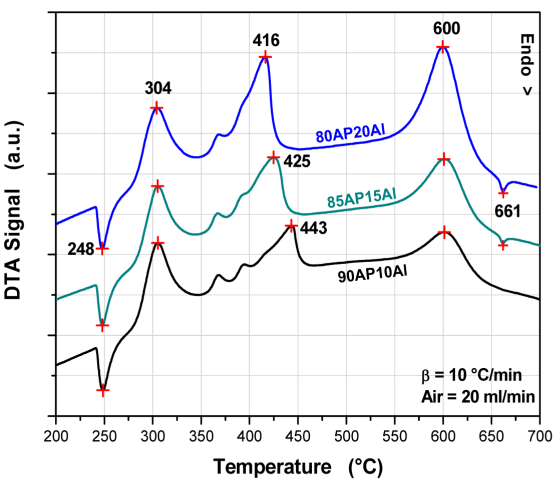

(a)

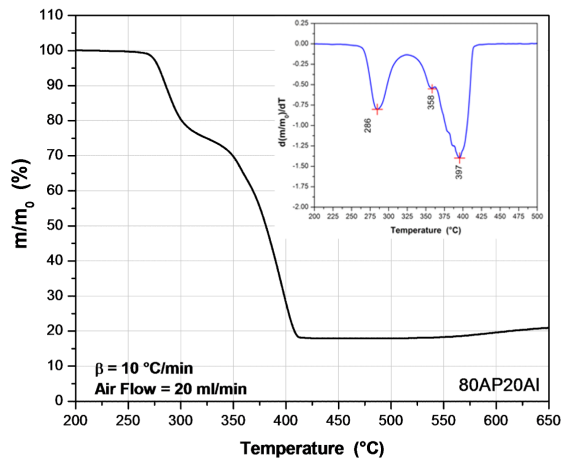

(c)

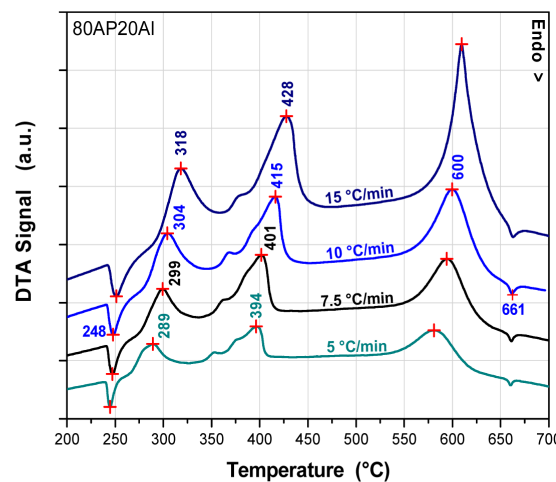

(b)

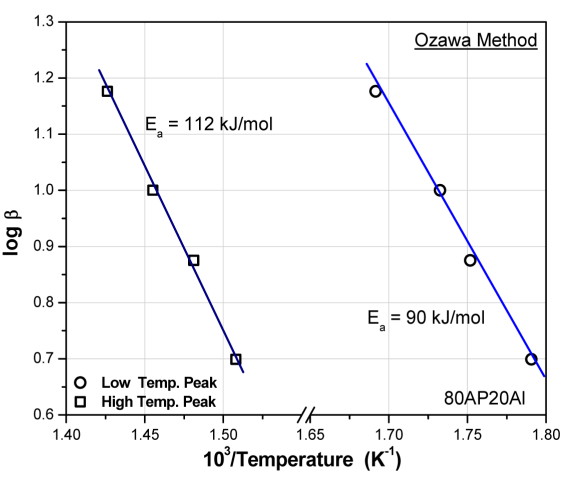

(d)

Figure 3. (a) DTA thermodiagrams obtained from different AP/Al chemical compositions; (b) Thermograms obtained at different heating rates from the propellant composition of $80 \mathrm{wt} \% \mathrm{AP}-20 \mathrm{wt} \% \mathrm{Al}$; (c) TGA and derivative TGA curves; (d) Activation energies from the same propellant calculated by Ozawa method. 
thermal decomposition with the present experimental conditions gave for the low temperature peak a mean value of $90 \mathrm{~kJ} / \mathrm{mol}$ and for the high temperature peak $112 \mathrm{~kJ} / \mathrm{mol}$. Comparing the values of the activation energy $\mathrm{E}_{\mathrm{a}}$ obtained from pure AP, then the presence of aluminum particles only modified the kinetics of the chemical event occurring at high temperature (Table 1).

\subsection{Thermal Decomposition of AP-Zn System}

On the other hand, thermal analysis was carried out to different chemical compositions of AP/Zn propellants following the same experimental procedures. In this case, zinc particles lead to a different behavior for AP decomposition. The decomposition of AP in presence of zinc particles seems to be concentrated in almost one step, as indicated on Figure 4(a) and Figure 4(b) From the peak shape observed in the first event $\left(290^{\circ} \mathrm{C}\right)$, a deconvolution analysis carried out on experimental data strongly suggest the presence of the first peak already observed in pure AP at approximately the same temperature superimposed with a second peak.

The last exothermic peak at $354^{\circ} \mathrm{C}$ was related to the initial zinc concentration, being associated to the oxidation of zinc. XRD analysis of the solid product

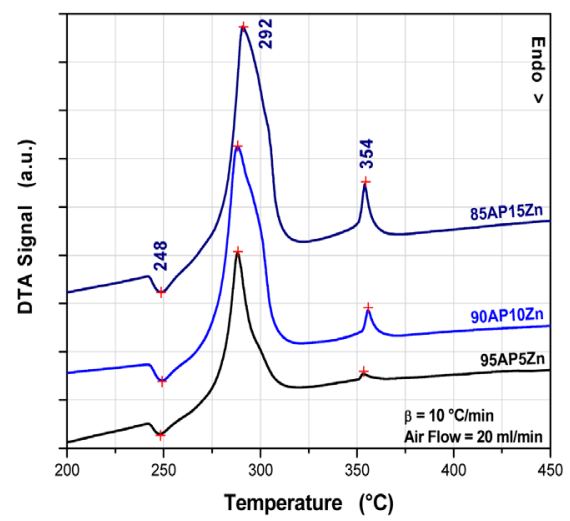

(a)

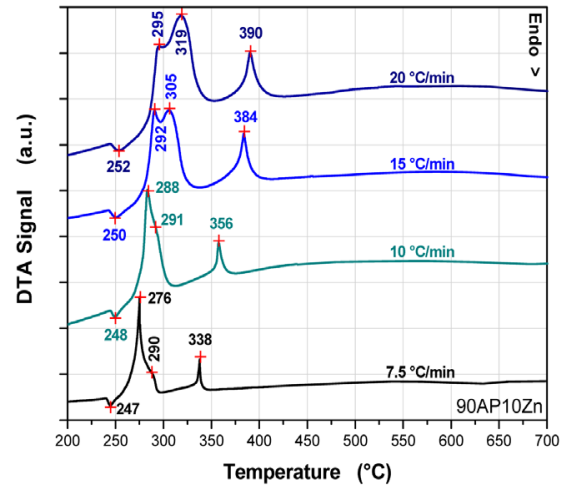

(c)

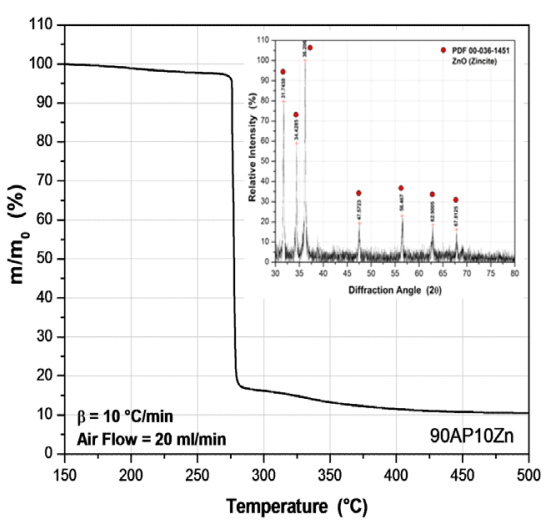

(b)

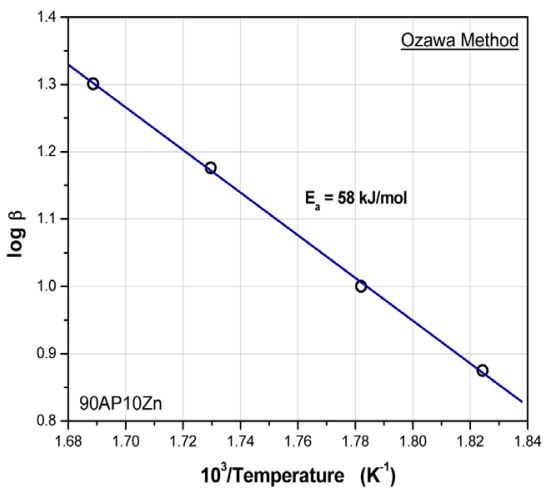

(d)

Figure 4. (a) DTA curves obtained from different AP/Zn chemical compositions; (b) TGA curve of sample $90 \mathrm{wt} \%$ AP - $10 \mathrm{wt} \% \mathrm{Zn}$ and XRD pattern of the solid combustion product; (c) DTA diagrams obtained at different heating rates from propellant composition $90 \mathrm{wt} \%$ AP - $10 \mathrm{wt} \% \mathrm{Zn}$; (d) Activation energy calculated from Ozawa method. 
fore, preliminary results suggest a catalytic effect of zinc particles on the thermal decomposition of AP leading to zinc oxide as the only final solid combustion product. Once again, an attempt was made to compare the kinetic parameters of non-isothermal decomposition of AP in presence of zinc particles. Concerning the thermal decomposition of $90 \mathrm{wt} \% \mathrm{AP}-10 \mathrm{wt} \% \mathrm{Zn}$ propellant at different heating rates, Figure 4 (c) corroborates the suggested presence of a second event during the thermal decomposition of AP in presence of zinc particles, corresponding to $\mathrm{ZnO}$ formation, fulfilling the one step decomposition behavior required to achieve a catalyzed propellant.

Concerning the activation energies $\mathrm{E}_{\mathrm{a}}$ calculated by Ozawa method for $\mathrm{AP} /$ Zinc decomposition and considering the presence of just one main event, taking into account that the peaks observed at $290^{\circ} \mathrm{C}, 291^{\circ} \mathrm{C}, 292^{\circ} \mathrm{C}$ and $295^{\circ} \mathrm{C}$ correspond to the same event, experimental data gave a mean activation energy of approximately $58 \mathrm{~kJ} / \mathrm{mol}$ (Figure 4(d)). Comparing the lowest activation energy obtained from the AP/Aluminum system (Table 1), the present results suggest that the presence of zinc particles appreciably reduce the potential barrier of ammonium perchlorate to thermal decomposition.

\subsection{Thermal Decomposition of AP-Al-Zn System}

A burning rate catalyst or burning rate modifier, usually incorporated at concentrations between 1 to $3 \mathrm{wt} \%$, helps to accelerate the combustion and increases the value of the propellant burning rate [23]. From Figure 3(a) and Figure 4(a), it is notorious that zinc particles are accelerating the combustion mechanism by reducing the numerous stages of AP decomposition in just one main event. Thermal analysis results shown on Figure 5(a) correspond to the decomposition of the $80 \mathrm{wt} \% \mathrm{AP}-20 \mathrm{wt} \% \mathrm{Al}$ with the addition of $2 \mathrm{wt} \%$ zinc particles, leading to the nominal chemical composition of $78.4 \mathrm{wt} \% \mathrm{AP}-19.6 \mathrm{wt} \% \mathrm{Al}-2 \mathrm{wt} \% \mathrm{Zn}$. The thermograms shown on Figure 5(b) strongly suggest that the combustion of this material is proceeding in one fast step where TGA diagram indicates the large production of gases in this only event, behavior typical of an energetic propellant. Concerning the activation energies $\mathrm{E}_{\mathrm{a}}$ calculated by Ozawa method for this $\mathrm{AP} / \mathrm{Al} / \mathrm{Zinc}$ decomposition and considering the presence of the only peak ob-

Table 1. Kinetics parameters obtained from the different propellants mixtures.

\begin{tabular}{cccccc}
\hline $\begin{array}{c}\text { Composition } \\
(\mathrm{wt} \%)\end{array}$ & $\begin{array}{c}\text { Peak Temp. } \\
\left({ }^{\circ} \mathrm{C}\right)\end{array}$ & $\begin{array}{c}\text { Ozawa } \\
\mathrm{E}_{\mathrm{a}}(\mathrm{kJ} / \mathrm{mol})\end{array}$ & $\begin{array}{c}\text { Kissinger } \\
\mathrm{E}_{\mathrm{a}}(\mathrm{kJ} / \mathrm{mol})\end{array}$ & $\begin{array}{c}\mathrm{A} \\
\left(\mathrm{min}^{-1}\right)\end{array}$ & $\begin{array}{c}\Delta \mathrm{H} \\
(\mathrm{J} / \mathrm{g})\end{array}$ \\
\hline 100 AP & 303 & 91 & 88 & $2.19 \times 10^{7}$ & -355 \\
& 462 & 229 & 226 & $8.34 \times 10^{15}$ & -748 \\
& 304 & 90 & 86 & $1.98 \times 10^{7}$ & -356 \\
80AP20Al & 425 & 112 & 106 & $2.87 \times 10^{7}$ & -1075 \\
& 288 & 58 & 55 & $5.57 \times 10^{4}$ & -1806 \\
90AP10Zn & 285 & 44 & 42 & $2.23 \times 10^{3}$ & -2042 \\
\hline
\end{tabular}




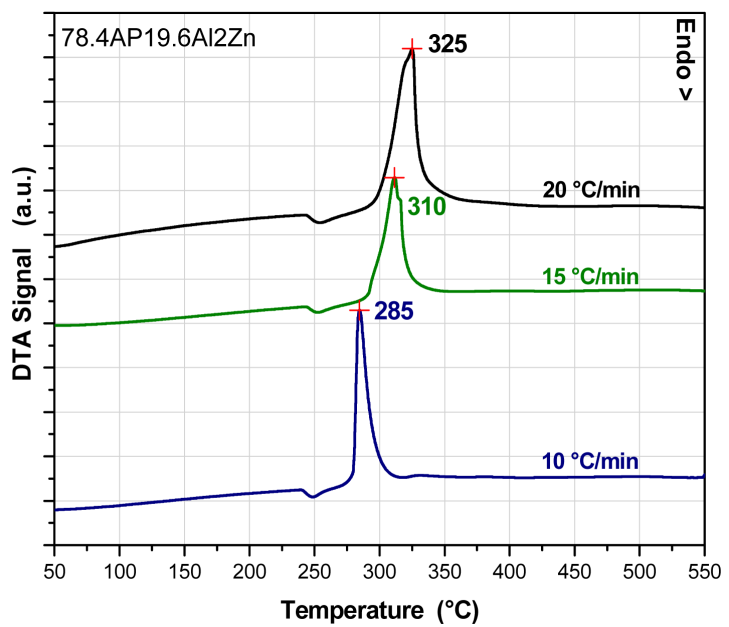

(a)

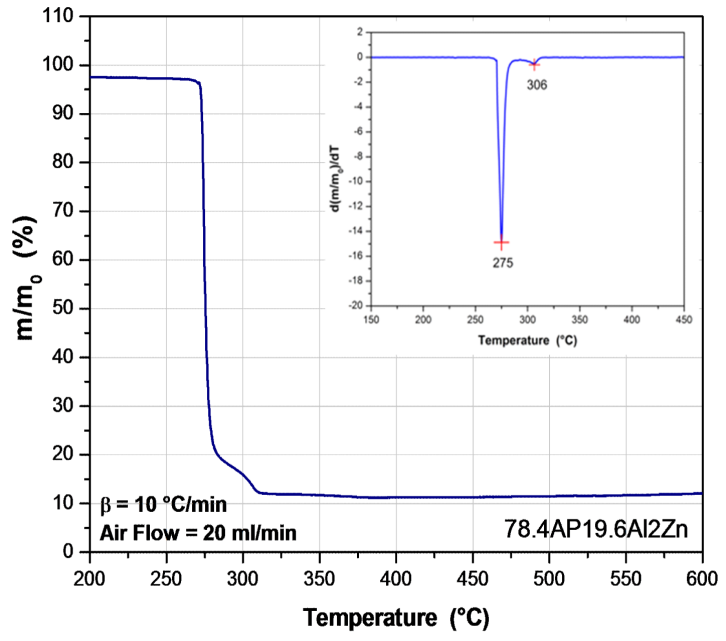

(b)

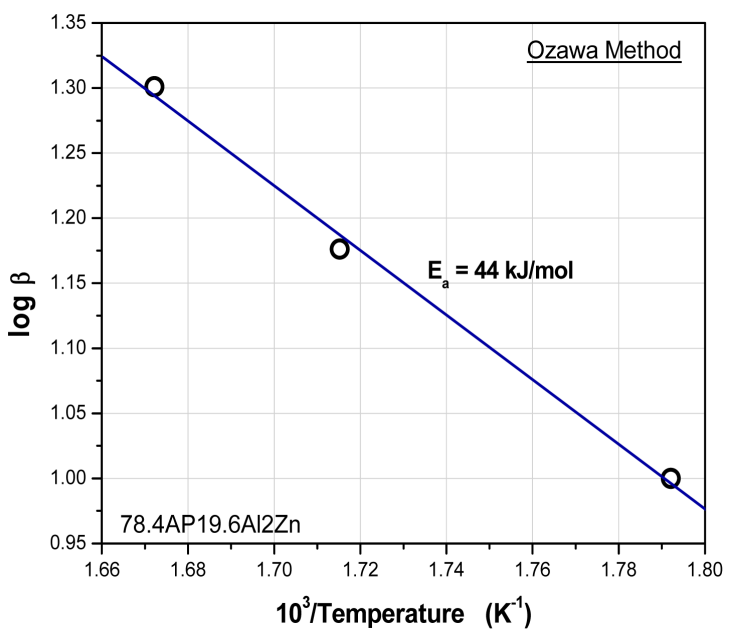

(c)

Figure 5. (a) Differential thermal analysis results with different heating rates obtained from PA/Al/Zn propellant; (b) TGA and derivative TGA curves of propellant $78.4 \mathrm{wt} \%$ AP - $19.6 \mathrm{wt} \% \mathrm{Al}-2 \mathrm{wt} \% \mathrm{Zn}$; (c) Activation energy of the same material calculated from Ozawa method. 
served, the activation energy $\mathrm{E}_{\mathrm{a}}$ calculated gives a value of $44 \mathrm{~kJ} / \mathrm{mol}$ (Figure $5(c)$ ), quite similar to the value calculated by Kissinger method (Table 1 ).

The present work only gives experimental results and no attempt was made to get a mechanistic explanation of the effect of metallic zinc on AP thermal decomposition. Nevertheless, a compound capable to affect the rate of chemical reaction by providing a lower energy profile is the basic characteristic of a catalyst. Therefore, the kinetic parameters obtained in the present case for the thermal decomposition of AP (Table 1), strongly suggest the catalytic behavior of zinc particles.

\section{Conclusion}

The Ozawa and Kissinger methods applied to DTA technique revealed a linear relationship between peak temperature and heating rate. Both techniques were used to determine the kinetics parameters of the thermal decomposition reaction of the energetic materials $\mathrm{AP}, \mathrm{AP} / \mathrm{Al}, \mathrm{AP} / \mathrm{Zn}$ and $\mathrm{AP} / \mathrm{Al} / \mathrm{Zn}$. The activation energies $\mathrm{E}_{\mathrm{a}}$ obtained from both methods gave equivalent values in all cases. The activation energy for AP decomposition with the present experimental conditions is in good agreement with those reported before, finding in this case for the low temperature peak a mean activation energy of $91 \mathrm{~kJ} / \mathrm{mol}$ and for the high temperature peak a mean activation energy of $229 \mathrm{~kJ} / \mathrm{mol}$. PA/aluminum decomposition with the same experimental conditions gave for the low temperature peak a mean value of $90 \mathrm{~kJ} / \mathrm{mol}$ and $112 \mathrm{~kJ} / \mathrm{mol}$ for the high temperature peak. According to the present analysis, the presence of aluminum particles only modified the kinetic scheme of the high temperature event. Regarding the $\mathrm{PA} /$ zinc decomposition, it was found $\mathrm{ZnO}$ as final solid combustion product, decomposition reaction taking place basically in one main event, experimental data giving mean activation energy of approximately $58 \mathrm{~kJ} / \mathrm{mol}$. Considering a potential catalytic effect of zinc particles on AP, thermal decomposition of the system $\mathrm{PA} / \mathrm{Al} / \mathrm{Zn}$ was evaluated. Thermal analysis results strongly suggest for the material having chemical composition $78.4 \mathrm{wt} \% \mathrm{PA} / 19.6 \mathrm{wt} \% \mathrm{Al} / 2.0 \mathrm{wt} \%$ $\mathrm{Zn}$, that combustion proceeds in one fast step as required to become a propellant, presenting an activation energy $\mathrm{E}_{\mathrm{a}}$ calculated by the Ozawa method of 44 $\mathrm{kJ} / \mathrm{mol}$.

\section{References}

[1] Davenas, A. (1993) Solid Rocket Propulsion Technology. Pergamon Press, Oxford.

[2] Halawy, S.A. and Al-Shihry, S.S. (1999) Role of the Acidic-Basic Characters of Some Metal Oxides in the Pyrolysis of Ammonium Perchlorate. Journal of Thermal Analysis and Calorimetry, 55, 833-840. https://doi.org/10.1023/A:1010129732656

[3] Komarov, V.F. (1999) Catalysis and Inhibition of the Combustion of Ammonium Perchlorate Based Solid Propellants. Combustion Explosive and Shock Waves, 35, 670-683. https://doi.org/10.1007/BF02674542

[4] Humble, R.W., Henry, G.N. and Larson, W.J. (1995) Space Propulsion Analysis and Design. McGraw-Hill, New York.

[5] Sutton, G.P. and Biblarz, O. (2001) Rocket Propulsion Elements. 7th Edition, John 
Wiley, Hoboken.

[6] Doll, D.W. and Lund, G.K. (1992) Magnesium Neutralized Propellant. Journal of Propulsuion and Power, 8, 1185-1191. https://doi.org/10.2514/3.11460

[7] Song, M., Chen, M. and Zhang, Z. (2008) Effect of Zinc Powders on the Thermal Decomposition of Ammonium Perchlorate. Propellants, Explosives, Pyrotechnics, 33, 261-265. https://doi.org/10.1002/prep.200800222

[8] Chaturvedi, S. and Dave, P.N. (2013) A Review on the Use of Nanometals as Catalyst for the Thermal Decomposition of Ammonium Perchlorate. Journal of Saudi Chemical Society, 17, 135-149. https://doi.org/10.1016/j.jscs.2011.05.009

[9] Kohga, M. and Tsuzuki, H. (2010) Crystal Habit Modification of Ammonium Perchlorate by Ethylene Glycol. Advanced Powder Technology, 21, 443-447.

https://doi.org/10.1016/j.apt.2010.01.004

[10] Keenan, A.G. and Siegmund, R.F. (1969) Thermal Decomposition of Ammonium Perchlorate. Quarterly Review of the Chemical Society, 23, 430-452. https://doi.org/10.1039/qr9692300430

[11] Jacobs, P.W.M. and Whitehead, H.M. (1969) Decomposition and Combustion of Ammonium Perchlorate. Chemical Reviews, 69, 551-590. https://doi.org/10.1021/cr60260a005

[12] Boldyrev, V.V. (2006) Thermal Decomposition of Ammonium Perchlorate. Thermochimica Acta, 443, 1-36.

[13] Vyazovkin, S. and Wight, C.A. (1999) Kinetics of Thermal Decomposition of Cubic Ammonium Perchlorate. Chemistry of Materials, 11, 3386-3393.

https://doi.org/10.1021/cm9904382

[14] Heath, G.A. and Majer, J.R. (1964) Mass Spectrometric Study of the Thermal Decomposition of Ammonium Perchlorate. Transactions of the Faraday Society, 60, 1783-1791. https://doi.org/10.1039/tf9646001783

[15] Sammons, G.D. (1969) Dynamic Calorimetric Solid Propellant Combustion Studies. AIAA 5th Propulsion Joint Specialist Conference, Colorado, 9-13 June 1969, 504-509.

[16] Kishore, K., Verneker, V.R.P. and Mohan, V.K. (1975) Differential Scanning Calorimetric Studies on Ammonium Perchlorate. Thermochimica Acta, 13, 277-292.

[17] Matecic, S., Fiamengo, I. and Suceska, M. (2010) Applicability of Non-Isothermal DSC and Ozawa Method for Studying Kinetics of Double Base Propellant Decomposition. Central European Journal of Energetic Materials, 7, 233-251.

[18] Rocco, J.A., Lima, J.E., Frutuoso, A.G., Iha, K., Ionashiro, M., Matos, J.R. and Suarez, M.E. (2004) Thermal Degradation of a Composite Solid Propellant Examined by DSC. Journal of Thermal Analysis and Calorimetry, 75, 551-557. https://doi.org/10.1023/B:JTAN.0000027145.14854.f0

[19] Ozawa, T. (1970) Kinetic Analysis of Derivative Curves in Thermal Analysis. Journal of Thermal Analysis and Calorimetry, 2, 301-324.

https://doi.org/10.1007/BF01911411

[20] Sanchez-Jimenez, P.E., Criado, J.M. and Perez-Maqueda, L.A. (2008) Kissinger Kinetic Analysis of Data Obtained under Different Heating Schedules. Journal of Thermal Analysis and Calorimetry, 94, 427-432. https://doi.org/10.1007/s10973-008-9200-2

[21] Seetharamacharyulu, D., Mallya, R.M., Kumar, R.N. and Pai Verneker, V.R. (1981) Combustion and Thermal Decomposition of Ammonium Perchlorate-Aluminium Composite Pellets: Mechanism for Aluminum Participation. Combustion Science 
and Technology, 25, 147-151. https://doi.org/10.1080/00102208108547514

[22] Pai Verneker, V.R., Seetharamacharyulu, D. and Mallya, R.M. (1979) Combustion of Ammonium Perchlorate-Aluminium Mixtures. Journal of Spacecraft and Rockets, 16, 436-438. https://doi.org/10.2514/3.28020

[23] Kubota, N. (2002) Propellants and Explosives: Thermochemical Aspects of Combustion. Wiley, Hoboken.

Submit or recommend next manuscript to SCIRP and we will provide best service for you:

Accepting pre-submission inquiries through Email, Facebook, LinkedIn, Twitter, etc. A wide selection of journals (inclusive of 9 subjects, more than 200 journals) Providing 24-hour high-quality service User-friendly online submission system Fair and swift peer-review system Efficient typesetting and proofreading procedure Display of the result of downloads and visits, as well as the number of cited articles Maximum dissemination of your research work

Submit your manuscript at: http://papersubmission.scirp.org/ Or contact msa@scirp.org 